\title{
ANALISIS TINGKAT KEBERHASILAN REHABILITASI MANGROVE DI DESA PIRU KECAMATAN SERAM BARAT KABUPATEN SERAM BAGIAN BARAT
}

\author{
Amus Makaruku1, Rukmini Aliman ${ }^{2}$ \\ ${ }^{1}$ Dinas Lingkungan Hidup Kabupaten Seram Bagian Barat, Maluku, \\ ${ }^{2}$ Program Studi Ilmu Lingkungan, Institut Teknologi Yogyakarta
}

\begin{abstract}
ABSTRAK
Kabupaten Seram Bagian Barat memiliki potensi wisata, tambang maupun perikanan yang menyebabkan perubahan peruntukan lahan mangrove sebagai tempat wisata, pelabuhan dan permukiman. Penelitian ini bertujuan untuk mengukur tingkat keberhasilan rehabilitasi mangrove, mengukur tingkat pertumbuhan mangrove yang direhabilitasi, dan menganalisis faktor-faktor yang mempengaruhi keberhasilan mangrove yang di rehabilitasi di Desa Piru,Kecamatan Seram Barat, Kabupaten Seram Bagian Barat,Maluku dari bulan Maret sampai bulan Mei 2017.

Pengukuran keberhasilan hidup dan pertumbuhan mangrove dilakukan pada plot dengan ukuran 5 x 5 meter, sedangkan pengukuran faktor-faktor lingkungan yang mempengaruhi keberhasilan rehabilitasi mangrove menggunakan sub plot ukuran 1 x 1 meter. Analisis keberhasilan hidup mangrove manggunakan analisis kuantitaif deskriptif, sedangkan faktor-faktor lingkungan yang mempengaruhi keberhasilan rehabilitasi mangrove menggunakan analsis deskriptif.

Tingkat keberhasilan rehabilitasi dinilai kurang berhasil dimana persentase keberhasilan hidup anakan Rhizophora mucronata masih di bawah $70 \%$. Tingkat pertumbuhan anakan Rhizophora mucronata baik dari segi tinggi maupun jumlah daun mengalami pertambahan tetapi tidak merata pada seluruh plot. Faktor-faktor yang mempengaruhi keberhasilan rehabilitasi mangrove yaitu salinitas dan suhu masih dalam kisaran yang sesuai untuk Rhizophora sp. Substrat pada lokasi penelitian didominasi oleh substrat pasir. Pasang surut dan zonasi menunjukan kesesuaian untuk habitat Rhizophora sp. Keragaman benthos pada lokasi penelitian tergolong sedang dan paling dominan ditemukan dari kelas Gastropoda dan Bivalvia sebab kandungan substrat yang cocok untuk habitat kedua jenis ini.
\end{abstract}

Kata kunci : mangrove, rehabilitasi, keberhasilan pertumbuhan, faktor lingkungan

\section{ANALISYS OF SUCCESS RATE OF MANGROVE REHABILITATION IN PIRU VILLAGE, SUB DISTRICT OF WEST SERAM, WEST SERAM REGENCY}

\begin{abstract}
West Seram Regency has tourism, mining and fishery potential that causes changes in the designation of mangrove land as tourist attractions, ports and settlements This study aimed to measure the success rate of mangrove rehabilitation,
\end{abstract}


to measure the growth rate mangroves, and analyze factors that influence the success of mangroves rehabilitationin Piru Village, of Sub District West Seram, of West Seram Regency, Malukufrom March 2017 to May 2017. Measurement of life and growth of mangrove is done on plot with size of $5 \times 5$ meter, while measurement of environmental factors that influence the success of mangrove rehabilitation used sub plot size of $1 \times 1$ meter. Analysis of mangrove survival used descriptive quantitative analysis, while the environmental factors that affect the success of mangrove rehabilitation used descriptive analysis.The rehabilitation is considered less successful since the percentage of successful live of Rhizophora mucronata seedlings is still below 70\%. The growth rate of Rhizophora mucronata seedlings both in terms of height and number of leaves has increased although not evenly distributed across the plot. Factors affecting the success of mangrove rehabilitation i.e. salinity and temperature are still within the desired range for Rhizophora sp. The substrate at the study site was dominated by sand substrate. Tide characteristics of the study site zone area is suitable for Rhizophora sp. The benthos diversity at the study sites was moderate and most dominant was found in the Gastropoda and Bivalvene classes because the substrate content was suitable for the habitats of both species.

Key words : mangrove, rehabilitation, success of growth, environmental factors

\section{PENGANTAR}

Kabupaten Seram Bagian Barat memiliki potensi wisata, tambang maupun perikanan yang menyebabkan perubahan peruntukan lahan mangrove sebagai tempat wisata, pelabuhan dan permukiman. Perubahan peruntukan tersebut mengakibatkan beberapa ekosistem mangrove mengalami kerusakan, sehingga perlu dilakukan upaya penanaman kembali pohon mangrove sebagai suatu upaya konservasi kawasan pesisir. Degradasi mangrove memerlukan perhatian yang serius tidak hanya dari pemerintah saja, namun juga masyarakat terutama yang tinggal di wilayah pesisir dan masyarakat peduli lingkungan (Lembaga Swadaya Masyarakat atau LSM).
Salah satu upaya yang bisa dilakukan untuk mengatasinya adalah dengan upaya rehabilitasi. Kegiatan ini diharapkan mampu mengembalikan fungsi penting mangrove dalam kawasan pesisir. Agar tujuan rehabilitasi dapat tercapai, maka diperlukan keterlibatan secara aktif dari masyarakat setiap desa di pesisir. Luasan hutan mangrove di wilayah Kabupaten Seram Bagian Barat dalam waktu dua tahun terjadi penyusutan lahan mangrove sebesar 174 ha atau sekitar $7,4 \%$, hal ini berdampak pada perubahan punutupan lahan mangrove, karena adanya eksploitasi oleh masyarakat lokal yang tidak terkendali, perluasan pemukiman, perkebunan dan pembukaan tambak (Pattimahu, 2010). 
Ekosistem mangrove mempunyai manfaat penting dalam mendukung kehidupan manusia baik secara langsung maupun tidak langsung. Ekosistem mangrove memberi kontribusi secara nyata bagi peningkatan pendapatan masyarakat, devisa untuk daerah (desa/kelurahan, kecamatan, kabupaten/kota, provinsi), dan negara. produk yang diperoleh dari ekosistem mangrove berupa kayu bakar, bahan bangunan, pupuk, bahan baku kertas, bahan makanan, obat-obatan, minuman, peralatan rumah tangga, bahan baku tekstil dan kulit, lilin, madu, rekreasi, tempat pemancingan, dan lain-lain (Ghufran, 2012).

Tahun 2015 dan 2016 telah dilakukan rehabilitasi mangrove di Kecamatan Seram Barat dengan luas tanam masing-masing 0,38 ha dan 0,40 ha, walaupun belum menunjukan keberhasilan yang signifikan (Badan Lingkungan Hidup Kabupaten Seram Bagian Barat, 2016). Upaya pengelolaan hutan mangrove dari masyarakat dan pemerintah setempat dinilai belum memadai untuk mempertahankan dan meningkatkan keberlangsungan hidup hutan mangrove di sekitar Desa Eti, Teluk Piru (Ahmad, 2010). Hal ini mengindikasikan bahwa keberhasilan rehabilitasi mangrove perlu ditingkatkan lagi sehingga mencapai tujuan yang optimal.

Mengingat belum pernah diteliti tingkat keberhasilan rehabilitasi mangrove, maka penelitian ini penting untuk dilakukan. Tujuan penelitian ini adalah untuk (1) mengetahui tingkat keberhasilan hidup rehabilitasi mangrove, (2) menganalisis tingkat pertumbuhan mangrove yang direhabilitasi, (3) menganalisis faktor-faktor lingkungan (salinitas, suhu, pasang surut, zonasi dan substrat) yang mempengaruhi keberhasilan mangrove yang direhabilitasi.

\section{METODE PENELITIAN}

Penelitian ini dilaksanakan pada bulan Maret 2017 sampai bulan Mei 2017. Tempat penelitian dilaksanakan di Dusun Taman Jaya Desa Piru, Kecamatan Seram Barat, Kabupaten Seram Bagian Barat, Maluku. Populasi penelitian adalah semua pohon mangrove yang ditanam pada tahun 2015 dan tahun 2016 di Desa Piru Kecamatan Seram Barat, yaitu di lokasi Dusun Taman Jaya berjumlah 3.800 tanaman yang menempati areal 0,38 ha pada tahun 2015 dan 4.000 tanaman yang menempati areal 0,4 ha pada tahun 2016. Sampel penelitian adalah semua pohon mangrove yang termasuk di dalam petak ukur dengan jumlah sampel masing-masing 200 tanaman. 


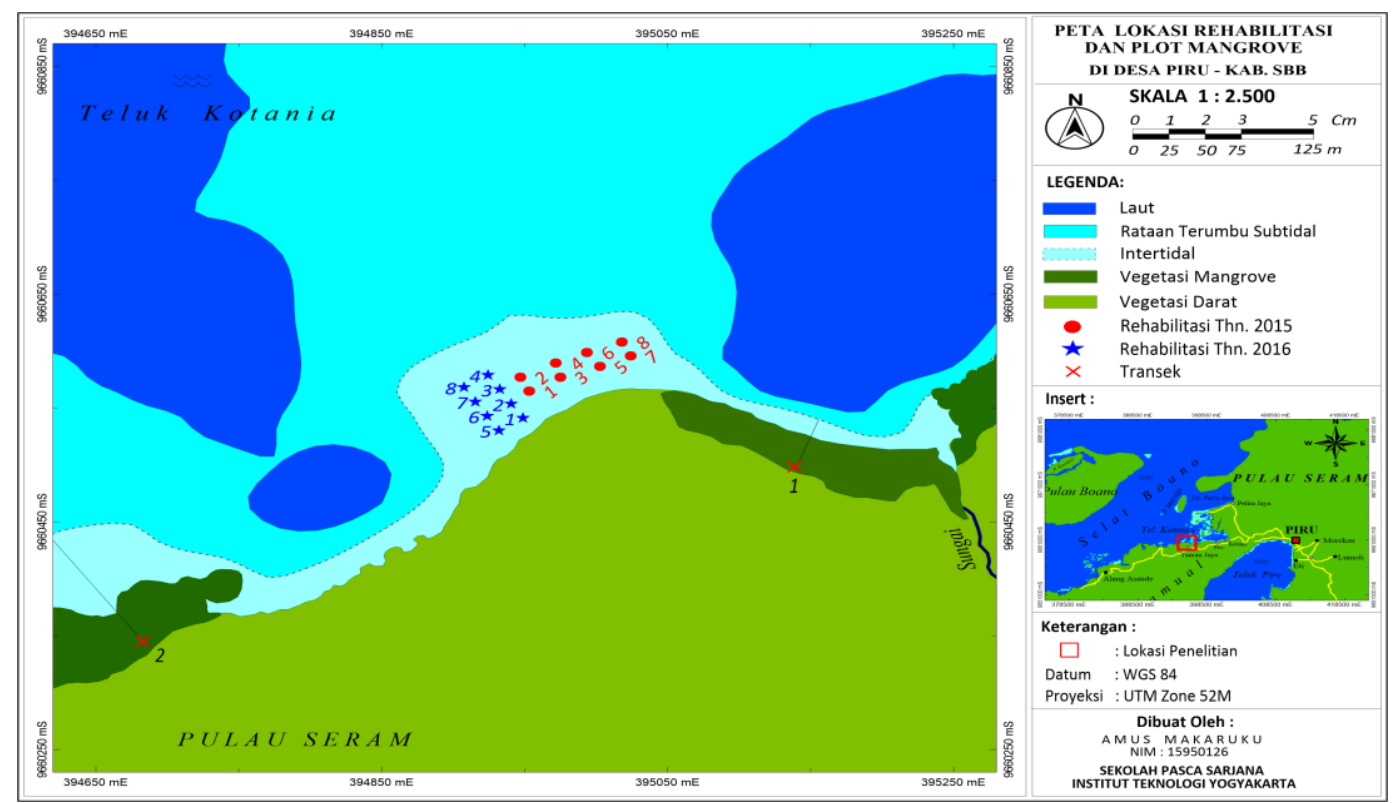

Gambar 1. Lokasi penelitian dan penempatan plot pengamatan

Pengumpulan data primer (tanaman hidup, tinggi anakan, jumlah daun, kondisi tumbuh tanaman sehat, salinitas, suhu, substrat, dan zonasi) dengan menggunakan metode jalur atau transek di lokasi penelitian yang dibuat tegak lurus garis pantai ke laut, mulai dari batas area penanaman dekat garis pantai sampai ke batas area penanaman ke arah laut. Pengambilan data dilakukan pada tanaman mangrove berdasarkan tahun tanam, yaitu tanaman mangrove yang ditanam pada tahun 2015 (0,38 ha) dan tahun $2016(0,40$ ha).

Setiap jalur ditempatkan plot pengamatan dengan ukuran $5 \mathrm{~m}$ x 5 m. Jarak antar plot 10 meter untuk tanaman yang direhabilitasi tahun
2015 dan untuk tanaman yang direbilitasi tahun 2016 jarak antar plot 15 meter, sedangkan jarak antar transek 20 meter (Gambar 1).

Penilaian faktor-faktor yang mempengaruhi pertumbuhan mangrove dilakukan dengan tahapan pengamatan dan pengambilan sampel di lapangan antara lain :

a. Salinitas.

Pengambilan data dilakukan langsung di lapangan dengan menggunakan salinometer.

b. Suhu.

Data Suhu diambil langsung di lapangan dengan menggunakan termometer.

c. Substrat.

Pengambilan contoh substrat menggunakan pipa paralon (PVC) kemudian disimpan dalam kantung plastik 
selanjutnya di analisis di laboratorium. Substrat dianalisis untuk menentukan persentase pasir, debu dan liat sehingga dapat diperoleh tipe substrat yang terdapat di lokasi penelitian.

d. Zonasi.

Pengumpulan data zonasi mangrove alami yang tumbuh di sekitar area rehabilitasi di ambil menggunakan metode transek dengan membuat transek garis yang tegak lurus dari arah pantai ke darat sampai tidak ditemukannya mangrove, dengan lebar transek 20 meter. Pengambilan sampel bentos dilakukan di dalam plot pengamatan $5 \times 5 \mathrm{~m}$ yang kemudian dibuat sub plot dengan ukuran $1 \mathrm{~m}$ x $1 \mathrm{~m}$. Pengambilan contoh sampel biota/benthos dilakukan satu kali pada saat air surut dan diambil pada setiap plot dengan metode core sampler cara membenamkan kotak berukuran $20 \times 20 \mathrm{~cm}^{2}$ sedalam $20 \mathrm{~cm}$ kemudian seluruh substrat yang berada di dalam kotak tersebut diangkat dan disimpan dalam kantong plastik dan diawetkan dengan formalin $4 \%$. Tiap kantong plastik kemudian diberi label untuk mempermudah pada waktu identifikasi.. Pengenalan benthos selanjutnya dilakukan di laboratorium.
Kelompok hewan arboreal yang hidup di atas daratan seperti serangga, ular pohon, primata dan burung yang tidak sepanjang hidupnya berada di habitat mangrove, tidak perlu beradaptasi dengan kondisi pasang surut (Nybakken, 1993 dalam Irwanto, 2006). Pengamatan hewan arboreal dilakukan dalam wilayah penelitian karena sering berpindah dari satu tempat ke tempat lain. Khusus untuk burung, waktu pengamatan dilakukan pada pukul 05.00 - 09.00 dan 16.00 - 18.00 selama 2 hari. Jenis hewan dicatat, diambil gambar dan selanjutnya diidentifikasi jenisnya menggunakan buku panduan lapangan pengenalan burung.

Keberhasilan hidup mangrove diketahui dengan mengukur persentase tumbuh yang dihitung dengan cara membandingkan jumlah tanaman yang ada pada suatu petak ukur dengan jumlah tanaman yang seharusnya ada di dalam petak ukur tersebut. Perhitungan persentase tumbuh dilakukan berdasarkan Peraturan Menteri Kehutanan No. P.70/Menhut-II/2008. Perhitungan persentase tumbuh tanaman menggunakan persamaan berikut.

$$
\begin{gathered}
T=\frac{\sum h_{i}}{\sum n_{i}} \times 100 \% \\
T=\frac{h_{1}+h_{2}+\ldots \ldots .+h_{n}}{n_{1}+n_{2}+\ldots \ldots .+n_{n}} \times 100 \%
\end{gathered}
$$

Keterangan :

$$
\mathrm{T}: \begin{aligned}
& \text { : Persentase } \\
& \text { tanaman sehat. }
\end{aligned}
$$


$\mathrm{h}_{\mathrm{i}} \quad$ : Jumlah tanaman yang terdapat pada petak ukur ke i.

$\mathrm{n}_{\mathrm{i}}$ : Jumlah tanaman yang seharusnya ada pada petak ukur ke i.

Penilaian mangrove yang direhabilitasi yang dilaksanakan selanjutnya dinilai keberhasilannya yaitu persentase tumbuh dinyatakan berhasil $(\geq 70 \%)$ dan kurang berhasil $(<70 \%)$.

Analisis pertumbuhan tanaman mangrove diketahui dengan menghitung tinggi batang dan jumlah daun selanjutnya masing-masing dihitung nilai rata-rata tiap plot, kemudian untuk mendapatkan totalnya.

Klasifikasi tinggi tanaman yang merupakan rata-rata tinggi tanaman diperoleh dengan merataratakan tinggi tanaman dibandingkan dengan jumlah tanamannya. Tinggi rata-rata per petak ukur dihitung dengan persamaan berikut.

$\mathrm{T}=\left(\sum \mathrm{t}_{\mathrm{i}} / \sum \mathrm{n}_{\mathrm{i}}\right)$

Dimana :

$\mathrm{T}$ : Tinggi rata-rata tanaman dalam petak ukur

$\mathrm{t}_{\mathrm{i}}$ : Tinggi setiap individu tanaman dalam petak ukur ke $\mathrm{i}$

$\mathrm{n}_{\mathrm{i}}$ : Jumlah tanaman pada petak ukur ke i

Jumlah daun rata-rata per petak ukur dihitung dengan rumus rerata (mean) yang paling umum digunakan :

$$
\begin{aligned}
& X=\frac{\sum_{i=1}^{n} X_{i}}{n} \\
& =\frac{X_{1}+X_{2}+\ldots+X_{n}}{n}
\end{aligned}
$$

Dimana :

$X \quad$ : Rata-rata hitung

$X_{i}$ : nilai sampel ke-i

$n$ : jumlah sampel

Faktor lingkungan yang mempengaruhi pertumbuhan mangrove di analisis secara deskriptif dengan membandingkan hasil pengamatan dan pengukuran faktor-faktor tersebut di lapangan dengan kesesuaian untuk faktor tersebut berdasarkan aturan yang berlaku. Salinitas dan suhu (Kepmen LH No. 51 Tahun 2004), pasang surut (Permenhut No. 70/Menhut/II/2008), kandungan substrat (segitiga shepard), zonasi mangrove (Permenhut No. 70/Menhut/II/2008).

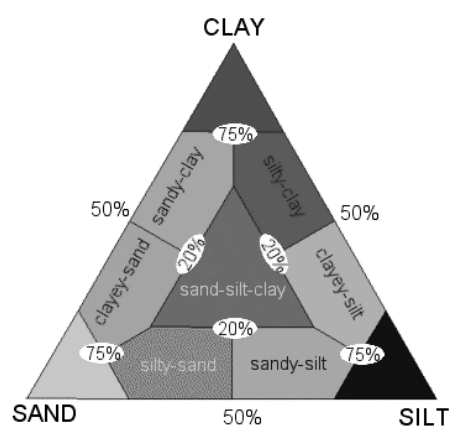

Gambar 2. Segitiga Shepard Kepadatan adalah jumlah individu per satuan luas atau per satuan volume (Brower dan Zar, 1997 dalam Bayan, 2014). Rumus yang digunakan sebagai berikut :

$D=\frac{n_{i}}{A}$ 
Keterangan :

D : Kepadatan benthos

$\mathrm{n}_{\mathrm{i}} \quad$ : jumlah individu benthos

A : luas area pengambilan sampel

Indeks Keanekaragaman jenis (H') menurut Odum (1994) :

$H^{\prime}=-\sum_{i=1}^{S} p_{i} L_{n} p_{i}$

Keterangan :

$H^{\prime} \quad$ : indeks

keanekaragaman

\section{Shannon-Wiener}

$p_{i} \quad$ : proporsi spesies ke-i $\left(\mathrm{n}_{\mathrm{i}}\right)$ terhadap jumlah total individu (N)
S : jumlah total spesies di dalam komunitas

Penentuan kategori

keanekaragaman spesies

dilakukan menggunakan

kategori indeks

keanekaragaman menurut

Odum (1993) seperti pada tabel

3.1.

Tabel 1. Kategori Indeks

Keanekaragaman

\begin{tabular}{|c|c|c|}
\hline No. & $\begin{array}{c}\text { Keanekaragaman } \\
\left(\mathrm{H}^{\prime}\right)\end{array}$ & Kategori \\
\hline 1 & $\mathrm{H}^{\prime}<2,0$ & Rendah \\
\hline 2 & $2,0<\mathrm{H}^{\prime}<3,0$ & Sedang \\
\hline 3 & $\mathrm{H}^{\prime}>3,0$ & Tinggi \\
\hline
\end{tabular}

$L_{n} \quad$ : logaritma nature

Tabel 2. Hasil analis keberhasilan rehabilitasi mangrove

\begin{tabular}{|c|c|c|}
\hline $\begin{array}{l}\text { Parameter/Faktor } \\
\text { Lingkungan }\end{array}$ & 2015 & 2016 \\
\hline Kesehatan tanaman & Sehat & Sehat \\
\hline Persentase hidup (\%) & 13,5 & 40,5 \\
\hline Tinggi tanaman $(\mathrm{cm})$ & 101 & 76 \\
\hline Jumlah daun (helai) & 37 & 5 \\
\hline Salinitas (\%o) & 28,3 & 28,6 \\
\hline Suhu $\left({ }^{\circ} \mathrm{C}\right)$ & 29,4 & 29,4 \\
\hline Kandungan substrat & Berpasir & Pasir berlempung \\
\hline Pasang surut & $\begin{array}{l}\text { Lama penggenangan rata-rata } \\
20 \text { hari/bulan }\end{array}$ & $\begin{array}{l}\text { Lama penggenangan rata-rata } \\
20 \text { hari/bulan }\end{array}$ \\
\hline Zonasi & Sesuai & Sesuai \\
\hline Aktifitas manusia & $\begin{array}{l}\text { Lintasan perahu, mancari } \\
\text { ikan dan kepiting }\end{array}$ & $\begin{array}{l}\text { Lintasan perahu, mancari } \\
\text { ikan dan kepiting }\end{array}$ \\
\hline $\begin{aligned} \text { Faktor lainnya : } \\
-\quad \text { Topografi }\end{aligned}$ & Landai (sesuai) & Landai (sesuai) \\
\hline - $\quad$ Arus & 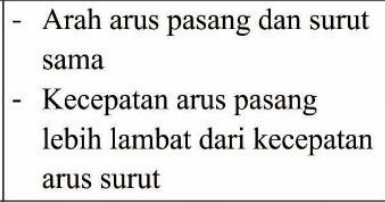 & $\begin{array}{l}\text { - Arah arus pasang dan surut } \\
\text { sama } \\
\text { - Kecepatan arus pasang } \\
\text { lebih lambat dari kecepatan } \\
\text { arus surut }\end{array}$ \\
\hline Benthos & $\begin{array}{ll}\text { - } & \text { Kepadatan (D) : } \\
& \text { individu/m² } \\
\text { - } & \text { Keragaman (H') : } 2,460 \\
\end{array}$ & $\begin{array}{l}\text { - } \text { Kepadatan (D) : } 1 \\
\text { individu/m² } \\
\text { - } \text { Keragaman (H') : 2,098 } \\
\end{array}$ \\
\hline Hewan Arboreal & Tidak dijumpai & Tidak dijumpai \\
\hline
\end{tabular}




\section{HASIL DAN PEMBAHASAN}

3.1. Tingkat keberhasilan rehabilitasi mangrove

Tingkat keberhasilan hidup mangrove (Rhizopora mucronata) yang ditanam tahun 2015 dan 2016 diketahui dengan mengukur persentase tumbuh tanaman yang ada pada petak ukur/plot. Berdasarkan hasil pengamatan menunjukan bahwa persentase hidup rata-rata tanaman yang ditanam pada tahun 2015 mencapai 13,5 \% (3 anakan/plot) atau 195 anakan/ha dan tanaman yang ditanam tahun 2016 mencapai $40,5 \%$ (10 anakan/plot) atau 648 anakan/ha

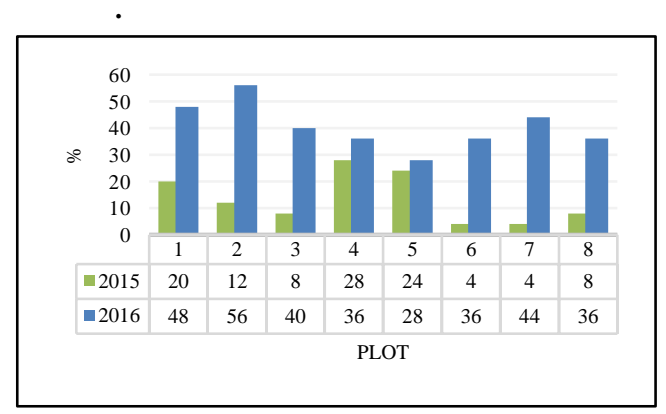

Gambar 3. Persentase hidup Rhizopora mucronata yang ditanam tahun 2015 dan 2016 pada setiap plot

Berdasarkan Gambar 3,
persentase hidup Rhizopora
mucronata yang ditanam tahun 2015
pada semua plot persentasenya
rendah, dimana pada plot 4 hanya
mencapai $28 \%$ ( 7 anakan), dan
persentase terendah terdapat pada
pada plot 6 dan 7 yang hanya
mencapai $4 \%$ (1 anakan) dimana
rata-rata mencapai $13,5 \%$. Hal ini
menunjukan bahwa jumlah anakan

yang hidup masih sangat rendah. Untuk Rhizopora mucronata yang ditanam pada tahun 2016, pada plot 5 memiliki tingkat hidup yang rendah, yaitu mencapai $28 \%$ (7 anakan), sedangkan yang lebih baik adalah plot 2 dimana keberhasilan hidup mencapai $56 \%$ (14 anakan) dengan rata-ratanya 40,5 \%. Hal ini menandakan bahwa tingkat keberhasilan hidup Rhizopora mucronata yang direhabilitasi dapat dikatakan kurang berhasil. Keberhasilan rehabilitasi mangrove berdasarkan Peraturan Menteri Kehutanan No. P.70/Menhut-II/2008, yaitu dinyatakan berhasil jika persentase tumbuh $\geq 70 \%$, dan dinyatakan kurang berhasil jika persentase tumbuhnya $<70 \%$. Persentase hidup anakan mangrove pada seluruh plot pengamatan berada di bawah $70 \%$.

Persentase hidup tanaman yang rendah di atas dapat dipengaruhi oleh beberapa faktor antara lain : tidak adanya kegiatan pemeliharaan lanjutan terhadap tanaman sehingga menyebabkan keberhasilan hidupnya rendah dan kurang adanya sosialisasi awal tentang teknis rehabilitasi/penanaman kepada masyarakat sehingga pengetahuan masyarakat mengenai cara melakukan penanaman sangat kurang. Selain itu, dengan tidak dilakukannya pemeliharaan tanaman maka tidak pula dilakukan penyulaman terhadap tanaman yang 
mati sehingga jumlah tanaman yang hidup relatif kecil. Penyulaman seharusnya dilakukan pada pemeliharaan tahun berjalan $(\mathrm{T}+0)$ yaitu 15-30 hari setelah penanaman dan pemeliharaan tahun pertama $(\mathrm{T}+1)$ tidak dilakukan. Tidak dilaksanakannya kegiatan pemeliharaan ini disebabkan karena tidak direncanakan kegiatan pemeliharaan dalam rehabilitasi yang dilakukan sehingga anggaran pemeliharaan tidak tersedia.

Faktor lingkungan lain yang mempengaruhi yaitu aktifitas masyarakat di sekitar area rehabilitasi. Masyarakat sering melakukan aktifitas di sekitar area ini diantaranya mengambil pasir untuk digunakan sebagai bahan bangunan, maupun mencari ikan dan kepiting dimana hal ini dapat menyebabkan tanaman menjadi rusak serta mati. lokasi penelitian yang memiliki pasir yang baik dikumpulkan oleh masyarakat kemudian diangkut menggunakan perahu melewati area rehabilitasi mangrove sehingga berpotensi merusak tanaman mangrove yang ada. Demikian juga aktifitas mencari ikan dan kepiting dilakukan masyarakat di area rehabilitasi baik itu menggunakan perahu pada saat pasang atau tanpa perahu pada waktu surut turut berpotensi merusak tanaman.

\subsection{Tingkat pertumbuhan mangrove}

Hasil pengamatan terhadap tanaman Rhizopora mucronata yang ditanam tahun 2015 dan 2016, terdapat perbedaan tinggi tanaman sejak ditanam yang menunjukan bahwa tanaman mengalami pertumbuhan tinggi. Rata-rata tinggi dan jumlah daun untuk tanaman yang ditanam tahun 2015 dan 2016 dapat dilihat pada Gambar 4 dan Gambar 5.

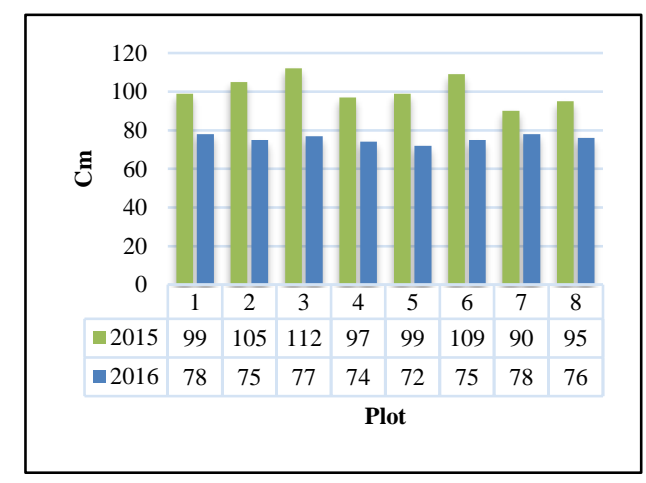

Gambar 4. Tinggi rata-rata tanaman pada setiap plot.

Tingkat pertumbuhan tanaman mangrove di lokasi penelitian sesuai data hasil pengukuran memperlihatkan bahwa mangrove yang direhabilitasi memiliki pertumbuhan yang baik, yaitu mengalami rata-rata pertambahan tinggi masing-masing sebesar $31 \mathrm{~cm}$ untuk mangrove yang direhabilitasi tahun 2015, dan rata-rata pertambahan tinggi $6 \mathrm{~cm}$ untuk mangrove yang direhabilitasi tahun 2016. Jika tinggi bibit siap ditanam yang siap ditanam berkisar antara 60 - $80 \mathrm{~cm}$ (nilai tengah 70), maka dapat diasumsikan bahwa rata-rata pertambahan tinggi tanaman mangrove di lokasi penelitian yaitu $15 \mathrm{~cm} /$ tahun. Pertumbuhan anakan 
mangrove yang baik ini dikarenakan lokasi rehabilitasi yang dekat dengan muara sungai, sehingga anakan mangrove terus mendapat suplai air tawar dari sungai tersebut. Mangrove yang tumbuh pada pantai yang tidak terdapat muara sungai, pertumbuhannya tidak optimal.

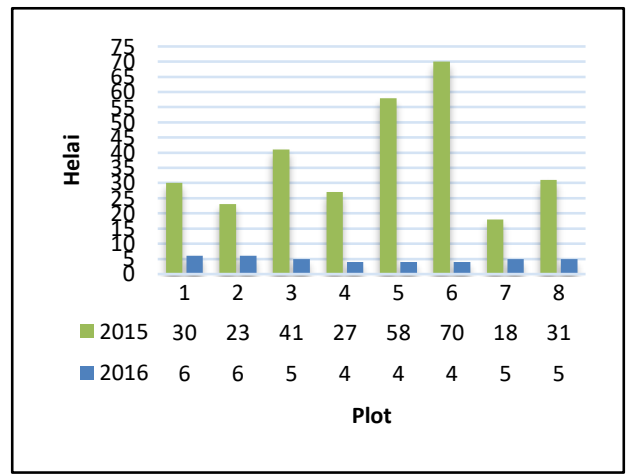

Gambar 5. Jumlah daun rata-rata tanaman pada tiap plot.

Jumlah daun pada tanaman yang direhabilitasi tahun 2015 menunjukan perkembangan yang baik dimana jumlah daun rata-rata pada setiap plot mengalami pertumbuhan. Rata-rata jumlah daun yang terbanyak berada pada plot 6 yaitu 70 helai sedangkan plot-plot yang lain mempunyai jumlah daun yang lebih sedikit. Rata-rata jumlah daun paling sedikit terdapat pada plot 7 yaitu 18 helai. Secara keseluruhan, rata-rata jumlah daun setiap plot adalah 37 helai per pohon. Hal ini dapat disebabkan oleh umur tanaman yang relatif lebih lama sehingga pertumbuhan daun makin baik.

Rata-rata Pertumbuhan daun pada tanaman yang direhabilitasi tahun 2016 pada gambar diatas tidak terlalu berbeda jauh pada setiap plot dimana menunjukan hasil yang hampir sama. Rata-rata jumlah daun terbanyak terdapat pada plot 1 dan 2 yaitu 6 helai per pohon, sedangkan paling sedikit berada pada plot 4, plot 5 dan plot 6 yaitu 4 helai per pohon. Rata-rata untuk seluruh plot, memiliki jumlah daun 5 helai per tanaman. Kurangnya jumlah daun pada Rhizopora mucronata yang direhabilitasi tahun 2016 ini dapat disebabkan oleh usia tanaman yang belum terlalu lama, dimana tanaman masih berada pada tahap penyesuaian dengan lingkungan hidupnya.

\subsection{Faktor-faktor lingkungan yang mempengaruhi kehidupan mangrove}

Hasil pengukuran salinitas dan suhu pada seluruh plot secara umum berada pada tingkat normal (Tabel $3)$.

Tabel 3. Hasil pengukuran faktor salinitas dan suhu

\begin{tabular}{|c|c|c|c|}
\hline \multirow{2}{*}{$\begin{array}{c}\text { Faktor } \\
\text { Lingkungan }\end{array}$} & \multicolumn{2}{|c|}{ Rata-Rata } & \multirow{2}{*}{$\begin{array}{l}\text { Baku } \\
\text { Mutu }\end{array}$} \\
\hline & $\begin{array}{l}\text { Penanaman } \\
2015\end{array}$ & $\begin{array}{l}\text { Penanaman } \\
2016\end{array}$ & \\
\hline $\begin{array}{l}\text { Salinitas } \\
(\%)\end{array}$ & 28,3 & 28,8 & $\begin{array}{l}10-30 \% \\
\text { (Permenhut } \\
\text { No. } 70 \\
\text { Tahun } \\
2008 \text { ) }\end{array}$ \\
\hline Suhu $\left({ }^{\circ} \mathrm{C}\right)$ & 29,4 & 29,3 & $\begin{array}{l}28-32^{\circ} \mathrm{C} \\
\text { (Permen } \\
\text { LH No. } 51 \\
\text { Tahun } \\
\text { 2004) }\end{array}$ \\
\hline
\end{tabular}

Salinitas air pada lokasi penelitian baik pada tanaman yang direhabilitasi tahun 2015 dan 2016 hampir sama yaitu $28,3 \%_{0}$ dan 28,8 $\%$. Hal ini disebabkan karena berada pada lokasi yang sama. 
Suhu perairan di lokasi penelitian menunjukan nilai yang hampir sama yaitu memiliki rata-rata $29,4{ }^{\circ} \mathrm{C}$ dan $29,3{ }^{\circ} \mathrm{C}$. Kisaran suhu ini sudah sesuai dengan baku mutu yang ditetapkan.

Analisa kandungan substrat pada lokasi penelitian dilakukan dengan mengukur persentase kandungan pasir, debu dan liat. Hasil penelitian menunjukan bahwa kandungan substrat pada lokasi penelitian sedikit berbeda dimana untuk tanaman yang ditanam tahun 2015 yaitu substrat berpasirdan lokasi rehabilitasi tahun 2016 dominan mengandung substrat pasir berlempung. Secara detail, lokasi penanaman tahun 2015, rata-rata persentase substrat pasir sebesar $50,22 \%$, substrat kerikil 25,29\% dan substrat lumpur 24,49 \%. Demikian pula area penanaman tahun 2016, rata-rata persentase substrat pada lokasi ini yaitu substrat pasir $47,20 \%$, substrat lumpur 29,27 $\%$, dan substrat kerikil 23,53\%.

Pasang surut adalah salah satu faktor yang sangat menentukan dalam menentukan zonasi, pertumbuhan, dan penyebaran kehidupan mangrove. Pasang surut juga membantu kahidupan ikan dan komunitas lainnya dalam hidup dan berasosiasi dengan ekosistem mangrove. pasang surut di perairan

Teluk Kotania mempunyai tipe pasang surut harian ganda (semi diurnal). Tipe pasang surut ini memiliki dua kali pasang dan dua kali surut dalam sehari namun mempunyai tinggi dan periode yang berbeda. Durasi atau Lama penggenangan untuk mangrove yang direhabilitasi tahun 2015 maupun 2016, rata-rata 20 hari per bulan atau tergenang $1-2$ kali per hari. Lamanya penggenangan maupun durasi pasang sudah sesuai untuk tumbuhnya jenis Rhizophora mucronata di lokasi penelitian.

Pengamatan zonasi mangrove dilakukan pada daerah sekitar lokasi penelitian, dimana dari 2 transek yang dibuat dengan panjang transek berkisar antara 45 - 124 meter. Lokasi transek sebagaimana terdapat pada gambar peta lokasi penelitian, yaitu transek 1 berada pada koordinat S $03^{\circ} 04^{\prime} 15,5^{\prime \prime}$ dan E 128 03'24,6" sedangkan transek 2 berada pada koordinat S $03^{\circ} 04^{\prime} 20,3^{\prime \prime}$ dan E $128^{\circ} 03^{\prime} 09,7^{\prime \prime}$. Transek 1 dan transek 2 adalah merupakan bekas kampung atau kampung yang telah ditinggalkan, sehingga mangrove yang ditemui cenderung beragam atau hampir sejenis.

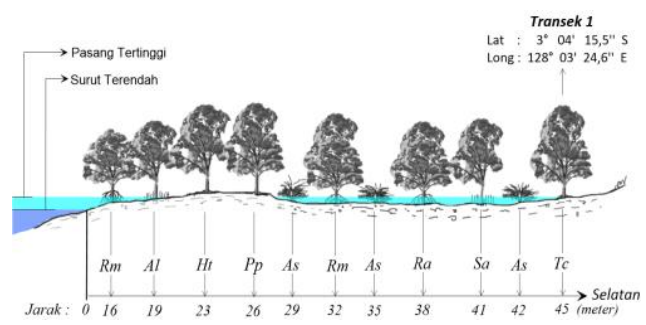

Gambar 6. Zonasi mangrove pada transek 1 . 


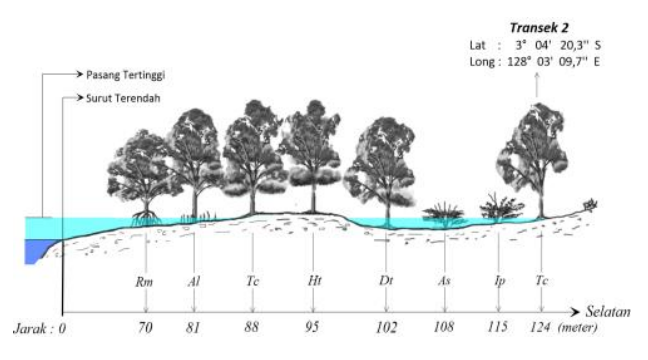

Gambar 7. Zonasi mangrove pada transek 2.

Keadaan hutan mangrove pada transek 1 dan 2 (Gambar 6 dan 7) memperlihatkan bahwa terdapat 4 (empat) zonasi dengan keadaan yang hampir sama dan didominasi oleh jenis mangrove yang hampir sama pula. Secara umum pada bagian depan didominasi oleh Rhizophora mucronatadanAvicennia lanata. Zonasi kedua merupakan zonasi campuran dimana terdapat Hibiscus tiliaceus L, Pongamia pinnata serta Acrostichum speciosum. Zonasi ketiga juga merupakan zonasi campuran antara Rhizophora mucronata, Acrostichum speciosumdan Rhizophora apiculata (transek 1)dan Derris trifoliata, Acrostichum speciosumdan Ipomoea pes-caprae (transek 2). Selanjutnya zonasi keempat didominasi oleh Terminalia catappa dan merupakan peralihan ke hutan darat. Lokasi Transek 1 yang berada dekat dengan muara sungai sehingga apabila pasang daerah bagian belakang dari transek ini terendam dan di situ juga tumbuh Rhizophora mucronatayang berasosiasi dengan mangrove lainnya. lokasi transek 2 merupakan bekas kampung.

Faktor lain diantaranya fisiografi/ topografi pantai pada lokasi penelitian yang menurut Lembaga Ilmu Pengetahuan Indonesia, Pusat Penelitian Laut Dalam Ambon, cenderung landai pada area rehabilitasi dan sedikit terjal pada sisi kiri dan kanan. Hal ini terlihat dari terdapat daerah yang dangkal tepat di depan area rehabilitasi, yang dimana saat surut cenderung berair dangkal dan kering.

Data Lembaga Ilmu

Pengetahuan Indonesia, Pusat Penelitian Laut Dalam Ambon, sekitar lokasi penelitian pola arus pada saat pasang maupun surut menunjukan pola/arah yang sama dengan kecepatan 0,05 - 0,5 m/s. Secara umum, arus pada Teluk Kotania mengalir mengikuti gerakan pasang dan surut yang terjadi dua kali dalam sehari. Pada saat pasang, kecepatan arus di sekitar lokasi penelitian cenderung lebih lambat dibandingkan kecepatan arus pada saat air surut. Keadaan ini memungkinkan sustrat akan terbawa oleh arus lebih besar. Selain itu, pola arus yang sama baik pada saat pasang maupun saat surut dapat menyebabkan sedimen yang dibawa tidak akan kembali ke are ini. Sedimen yang dapat mengendap cenderung didominasi oleh pasir. Hal ini sesuai dengan keadaan substrat pada lokasi penelitian yang didominasi oleh substrat pasir. 
3.4. Kepadatan dan Keragaman Benthos dan Hewan Arboreal

Hasil pengamatan serta identifikasi terhadap bentos pada lokasi penelitian Rhizophora mucronata yang direhabilitasi tahun 2015 terdapat 14 jenis benthos, yang terdiri dari 4 kelas yaitu Gastropoda, Bivalvia, Crustacea dan Lingulata, sedangkan untuk lokasi rehabilitasi tahun 2016 terdapat 11 jenis benthos, yang terdiri dari 3 kelas yaitu Gastropoda, Bivalvia dan Lingulata. Gastropoda ditemui hampir di seluruh plot, baik untuk lokasi rehabilitasi tahun 2015 maupun lokasi rehabilitasi tahun 2016 (Tabel 4).

Tabel 4. Penyebaran benthos pada lokasi penelitian

\begin{tabular}{|c|c|c|c|c|c|c|c|c|c|}
\hline \multirow{2}{*}{ Lokasi } & \multirow{2}{*}{ Kelas } & \multicolumn{8}{|c|}{ Plot } \\
\hline & & 1 & 2 & 3 & 4 & 5 & 6 & 7 & 8 \\
\hline \multirow{4}{*}{$\begin{array}{lr}\text { Lokasi } & \text { pengamatan } \\
\text { rehabilitasi tahun } 2015 & \text { area }\end{array}$} & Gastropoda & + & - & + & - & + & + & - & + \\
\hline & Bivalvia & - & + & + & - & + & + & + & + \\
\hline & Crustacea & - & - & + & - & - & - & - & - \\
\hline & Lingulata & - & - & - & + & - & - & - & - \\
\hline \multirow{4}{*}{$\begin{array}{lr}\text { Lokasi pengamatan } & \text { area } \\
\text { rehabilitasi tahun } 2016 & \end{array}$} & Gastropoda & + & + & + & + & + & + & + & + \\
\hline & Bivalvia & - & + & + & + & - & - & - & - \\
\hline & Crustacea & - & - & - & - & - & - & - & - \\
\hline & Lingulata & - & - & - & - & - & + & + & + \\
\hline
\end{tabular}

Keterangan $:+=$ ada, $-=$ tidak ada

Kepadatan jenis Benthos yang ditemukan pada lokasi rehabilitasi 2015 terdiri dari 8 jenis dari kelas Gastropoda, 4 jenis dari kelas Bivalvia, dan masing-masing 1 jenis dari kelas Crustacea dan kelas Lingulata. Gafrarium tumidum dari kelas Gastropoda memiliki kepadatan yang tinggi yaitu sebesar 0,625 individu $/ \mathrm{m}^{2}$, sedangkan jenis dengan kepadatan terendah yaitu Strobus urceus, Vexillum plicarium, Nassarius globosus, Umbonium vestiarium, Nassarius distortus, Callista impar, Scylla serrata, Lingula anatina, Atys cylindricus, dan Nassarius acuticostus dengan kepadatan $0,125 \quad$ individu $/ \mathrm{m}^{2}$. Keragaman benthos pada lokasi ini sebesar 2,460 yang menandakan bahwa indeks keanekaragaman ( $\left.\mathrm{H}^{\prime}\right)$ tergolong sedang $\left(2,0<\mathrm{H}^{\prime}<3,0\right)$.

Kepadatan Benthos yang ditemukan pada lokasi rehabilitasi mangrove tahun 2016 (Tabel 4.5) berasal dari 3 kelas, masing-masing kelas Gastropoda terdapat 5 jenis, kelas Bivalvia 5 jenis dan kelas Lingulata 1 jenis. Jenis dengan nilai kepadatan tertinggi yaitu Nassarius globosus dengan kepadatan mencapai 1 individu $/ \mathrm{m}^{2}$, kemudian Lingula anatina dengan kepadatan 0,75 individu $/ \mathrm{m}^{2}$, sedangkan kepadatan terendah yaitu Antigona lamellaris, Timoclea scandularis, Gafrarium tumidum, Anomalocardia squamosa, Imbricaria comularis, dan 
Nassarius limnaeiformis dengan kepadatan 0,125 individu $/ \mathrm{m}^{2}$. Secara keseluruhan, indeks keragaman mencapai 2,058 dimana juga tergolong sedang $\left(2,0<\mathrm{H}^{\prime}<3,0\right)$.

Secara umum analisis ini menunjukan bahwa kepadatan benthos yang terdapat pada lokasi penelitian tergolong kecil, karena rata-rata hanya 1 individu $/ \mathrm{m}^{2}$, dan indeks keragaman yang tergolong sedang sampai rendah bahkan tidak ada sama sekali karena pada plot tertentu hanya ditemukan 1 spesies benthos. Menurut Fitriana (2005), kemelimpahan makrozoobenthos berkorelasi negatif dengan kandungan tekstur liat, makin tingginya tingkat kandungan liat, makin rendah kemelimpahan makrozoobenthos. Hal ini sama seperti yang diungkapkan oleh Barnes (1987) dalam Amrul (2007) bahwa Tekstur sedimen akan mempengaruhi struktur komunitas dari hewan benthos. Benthos dari jenis Bivalvia menyukai tekstur berlumpur atau berpasir, Gastropoda memiliki penyebaran yang lebih luas karena mampu beradaptasi pada habitat air tawar ataupun laut dengan tekstur sedimen lunak atau keras. Pada umumnya Gastropoda lebih menyukai substrat pasir berlumpur.

Pada lokasi penelitian, selama pengamatan tidak ditemukan hewan arboreal yang menempati atau mencari makan di lokasi ini, karena keadaan tumbuhan mangrove yang baru direhabilitasi serta pertumbuhan mangrove yang masih terlalu kecil untuk hewan arboreal membuat sarang, bertengger dan mencari makan di sekitarnya.

\section{KESIMPULAN DAN SARAN}

4.1. Kesimpulan

Berdasarkan analisis penelitian maka dapat ditarik kesimpulan bahwa:

1. Tingkat keberhasilan rehabilitasi mangrove jenis Rhizophora mucronata pada lokasi penelitian dinilai kurang berhasilkarena persentase keberhasilan hidup anakan Rhizophora mucronata yang direhabilitasi $<70 \%$.

2. Tingkat pertumbuhan anakan Rhizophora mucronata yang ditanam untuk tinggi batang, anakan mengalami pertambahan tinggi rata-rata $15 \mathrm{~cm} /$ tahun dan pertambahan jumlah daun mencapai rata-rata 37 helai per pohon.

3. Faktor-faktor lingkungan pada lokasi penelitian yang berpengaruh terhadap kehidupan mangrove yaitu:

- Salinitas rata-rata $28,3 \%_{0}$ (area rehabilitasi tahun 2015) dan $28,8 \%$ o (area rehabilitasi tahun 2016).

- Suhu rata-rata $29,4{ }^{0} \mathrm{C}$ (area rehabilitasi tahun 2015) dan $29,3{ }^{0} \mathrm{C}$ (area rehabilitasi tahun 2015). 
- Tipe substrat secara umum didominasi oleh substrat berpasir.

- Tipe pasang surut di Teluk Kotania yaitu tipe harian ganda (semi diurnal) dengan lama penggenangan yang mencapai 20 hari per bulan.

- Zonasi mangrove alami di sekitar lokasi penelitian terdapat 4 zona dimana zona terdepan didominasi oleh Rhizophora mucronatadan Avicenia lanata.

- Fisiografi/topografi pantai cenderung landai,dan arus air laut baik saat pasang maupun surut mempunyai pola yang sama sehingga sedimen cenderung terbawa oleh arus.

- Bentos paling dominan ditemukan yaitu berasal dari kelas Gastropoda dan Bivalvia, dengan kerapatan tergolong rendah dimana hanya mencapai 1 individu $/ \mathrm{m}^{2}$ dengan tingkat keragaman tergolong sedang.

\subsection{Saran}

Sesuai dengan pembahasan dan kesimpulan di atas, maka ada beberapa saran yang hendak penulis sampaikan yaitu :

1. Perlu dilakukan penyulaman dan pemeliharaan terhadap anakan mangrove yang direhabilitasi sehingga dapat meningkatkan keberhasilan dari kegiatan rehabilitasi yang dilaksanakan.
2. Perlu dilakukan evaluasi lanjutan terhadap kegiatan rehabilitasi untuk dapat mengetahui solusi yang diperlukan berkaitan dengan tingkat keberhasilannya.

\section{DAFTAR PUSTAKA}

Ahmad, F., 2010. Kondisi Hutan Mangrove Teluk Piru, Seram Barat, Maluku. Jurnal Ilmu dan Teknologi Kelautan Tropis, Vol. 7, No.2, Hlm 731-743, Desember 2015.

Amrul, H.M.Z.N., 2007. Kualitas Fisika-Kimia Sedimen Serta Hubungannya Terhadap Struktur Komunitas Makrozoobenthos di Estuari Percut Sei Tuan Kabupaten Deli Serdang. Tesis, Badan Lingkungan Hidup Kabupaten Seram Bagian Barat, 2014. Status Lingkungan Hidup Daerah Kabupaten Seram Bagian Barat. Badan Lingkungan Hidup Kabupaten Seram Bagian Barat. Piru.

Bayan, I.E., 2014. Analisis Degradasi Fungsi Ekologi Mangrove Sebagai Habitat Makrozoobentos dan Pengelolaanya di Pantai Angke Kapuk, Jakarta 
Utara. Institut pertanian Bogor.

Fitriana, Y.R., 2003. Keanekaragaman dan Kemelimpahan

Makrozoobentos di Hutan Mangrove Hasil Rehabilitasi Tanaman Hutan Raya Ngurah Rai Bali. Jurnal Biodiversitas, Vol. 7, No.1, Hlm 67-72, Januari 2006.

Ghufran H. Kordi K.M., 2012. Ekosistem Mangrove : Potensi, Fungsi dan Pengelolaan. Penerbit PT Rineka Cipta, Jakarta.

Irwanto, 2006. Keanekaragaman Fauna Pada Habitat Mangrove. Yogyakarta.

Menteri Negara Lingkungan Hidup Republik Indonesia (2004). Keputusan Menteri Lingkungan Hidup Nomor 51 Tahun 2004 tentang Baku Mutu Air Laut Untuk Ekosistem Mangrove.

Menteri Kehutanan Republik Indonesia (2008). Peraturan Manteri Kehutanan Nomor P.70/Menhut-II/2008 tahun 2008, tentang Pedoman Teknis Rehabilitasi Hutan dan Lahan.
Penutupan Lahan

Mangrove di Kabupaten

Seram Bagian Barat

Maluku. Jurnal Hutan

Pulau-Pulau Kecil, Vol 1.

No. 1, Agustus 2016:22-27. 
